\author{
Сахно $^{1}$ В.П., Поляков ${ }^{1}$ В.М., Мурований ${ }^{2}$ I.С., Шарай ${ }^{1}$ C.M. \\ ${ }^{1}$ Національний транспортний університет \\ ${ }^{2}$ Луцький наиіональний технічний університет
}

\title{
ДО ВИБОРУ ТА ОБГРУНТУВАННЮ КОМПОНУВАЛЬНОЇ СХЕМИ МЕТРОБУСА ОСОБЛИВО ВЕЛИКОЇ МІСТКОСТІ
}

\begin{abstract}
Розглянуті кінематичний і силовий способи повороту причепа до поліпшення маневреності метробуса. Встановлені необхідні кути повороту керованих коліс першого або другого причепа, за яких забезпечуються нормовані показники маневреності. Показані переваги силового способу повороту колесами причепа. Визначена необхідна різниця крутних моментів на колесах причепа, за якої радіус повороту метробуса був би таким, як і з керованим першим причепом за кінематичного способу повороту.

Ключові слова: метробус, причіп, маневреність, зміщення, габаритна смуга руху, гібридна силова установка, траєкторія.
\end{abstract}

Постановка проблеми. За останнє десятиліття в США, країнах Південної Америки, Туреччині, Росії та в деяких країнах Свропи як новий вид пасажирських перевезень розвиваються Bus Rapid Transit - швидкісні автобусні перевезення. Цей вид пасажирського транспорту дешевший за метро, оскільки потребує при менших капіталовкладеннях налагодити пасажирські перевезення на маршрутах найбільших пасажиропотоків. В Києві ще у минулому році КМДА оголосила тендер на ТЕО для метробуса від Троєщини до Севастопольскої площі. Планується розробка метробусної лінії від Дарницької площі до Лісового масиву. Довжина метробусів може досягати 25-28 метрів. Маса до 45 тонн. Використання таких автотранспортних засобів повинно бути підтверджено вирішенням певних технічних проблем, пов'язаних з вибором енергетичної установки, масових і компонувальних параметрів, що у значній мірі визначають показники тягово-швидкісних властивостей, маневреності, керованості та екологічності метробусів.

Аналіз останніх досліджень. Одним із напрямків розвитку сучасних екологічно чистих АТЗ вважають гібридні силові установки на основі комбінації двигуна внутрішнього згоряння та електричної машини. Гібридні технології відомі більше 40 років. В силових установках легкових автомобілів використовують різні технології - електричні, гібридні, паливні елементи [1]. Перші спроби застосування гібридних силових установок на вантажних автомобілях починаються у 80-х роках XX століття. Компанія HinoMotors, Ltd., починаючи з 1981 року проводила дослідження дизель-електричних гібридних систем, в результаті чого у 1991 році почалися комерційні продажі та експлуатація гібридного дизельного автобуса великого класу [2].

Нові розробки в галузі створення багатоланкових АТЗ і методик оптимізації їх конструкцій орієнтовані на мінімізацію витрат палива, енергії, поліпшення показників маневреності та керованості. Багато теоретичних даних 3 питань оптимізації складних механічних систем i мультіоб'єктивних методів оптимізації наведено в [3]. У роботі [4] розглянуто схемні рішення та особливості побудови автотранспортних засобів з гібридною силовою установкою, електричні системи та комплекси гібридного автомобіля. Аналіз конструкцій та класифікація багатовісних автомобілів традиційної конструкції, загальні закономірності їх руху розглянуто в роботі [5]. При цьому однією 3 невирішених проблем $є$ раціональний розподіл потужності між обома силовими установками в залежності від умов експлуатації АТЗ.

Формування цілей роботи. Метою роботи $€$ визначення параметрів гібридної силової установки, вибір та обгрунтування компонувальної схеми метробуса, за яких забезпечуються необхідні показники тягово-швидкісних властивостей та маневреності.

Основна частина. Проведеними раніше дослідженнями встановлено, що метробус може конкурувати з метро у випадку його пасажиромісткості $180 \ldots 250$ пасажирів і інтервалу руху $30 \ldots 45$ с. Така пасажиромісткість може бути забезпечена тільки триланковим метробусом у складі автобуса (як тягача) і двох причепів. Загальна маса метробуса може бути прийнятою на рівні $38000 \ldots 40000$ кг (маса тривісного шарнірно-з'єднаного автобуса - 28000 + маса причепа - 10000...12000 кг). Загальна довжина такого метробуса на рівні 25000 мм, рис. 1.

Визначимо необхідно потужність гібридної силової установки, виходячи 3 умови, що потужність дизеля повинна забезпечити усталений рух метробуса зі швидкістю $25 \mathrm{~m} / \mathrm{c}$, а дизель і електродвигун повинні забезпечити розганяння метробуса на нижчих передачах $(1,2$ в коробці 
передач) 3 прискоренням $1,5 \ldots .1,0 \mathrm{~m} / \mathrm{c}^{2}$.

Запишемо рівняння потужнісного балансу для цих двох режимів руху метробуса [6]. Отримаємо:

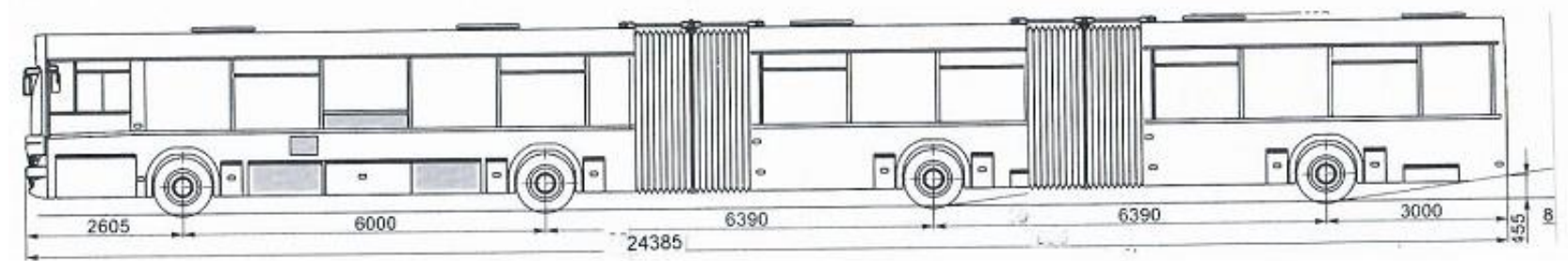

Рисунок 1 - Компонувальна схема триланкового метробуса

$$
\begin{gathered}
N_{e v}=\frac{f_{v} \times M_{a} \times g \times v_{\text {max }}+k_{B} \times F \times v_{\text {max }}^{3}}{1000 \times \eta_{M}}, \\
N_{e P}=\frac{f_{0} \times M_{a} \times g \times v_{p}+\delta_{i} \times M_{a} \times v_{p} \times \frac{d v_{i}}{d t}}{1000 \times \eta_{M}},
\end{gathered}
$$

де $N_{\mathrm{ev}}, N_{\mathrm{P}}$ - потужність дизеля і гібридної силової установки відповідно;

$f_{0}, f_{\mathrm{v}}$ - коефіцієнти опору кочення за швидкості $1 \mathrm{~m} / \mathrm{c}$ і максимальної відповідно, $f_{0}=0,02 ; f_{\mathrm{v}}=0,024$;

$v_{\mathrm{p}}, v_{\max }$ - швидкість в процесі розгону і максимальна швидкість метробуса, $v_{\mathrm{p}}=2.5 \mathrm{~m} / \mathrm{c}, v_{\max }=25 \mathrm{~m} / \mathrm{c}$;

$k_{\mathrm{B}}-$ коефіцієнт опору повітря, $k_{\mathrm{B}}=0,6 \mathrm{Hc}^{2} / \mathrm{m}^{4}$;

$F$ - площа поперечного перерізу метробуса, $F=7,5 \mathrm{~m}^{2}$;

$M_{\mathrm{a}}-$ загальна маса автобуса, $M_{\mathrm{a}}=40000$ кг;

$g$ - прискорення вільного падіння;

$\eta_{\mathrm{M}}-$ механічний коефіцієнт корисної дії трансмісії, $\eta_{\mathrm{M}}=0,9$

$\frac{d v}{d t}$ - прискорення метробуса на першій передачі в коробці передач, $\frac{d v}{d t}=1,5 \mathrm{~m} / \mathrm{c}^{2}$.

За обраними вихідними даними потужність дизеля склала 300 кВт, потужність гібридної силової установки - 385 кВт. У якості електродвигуна можна використати двигун BRASA HSM112/18/13, швидкісна характеристика якого наведена на рис. 2. Цей двигун використовується разом 3 редуктором, передаточне відношення якого складає 9,7.

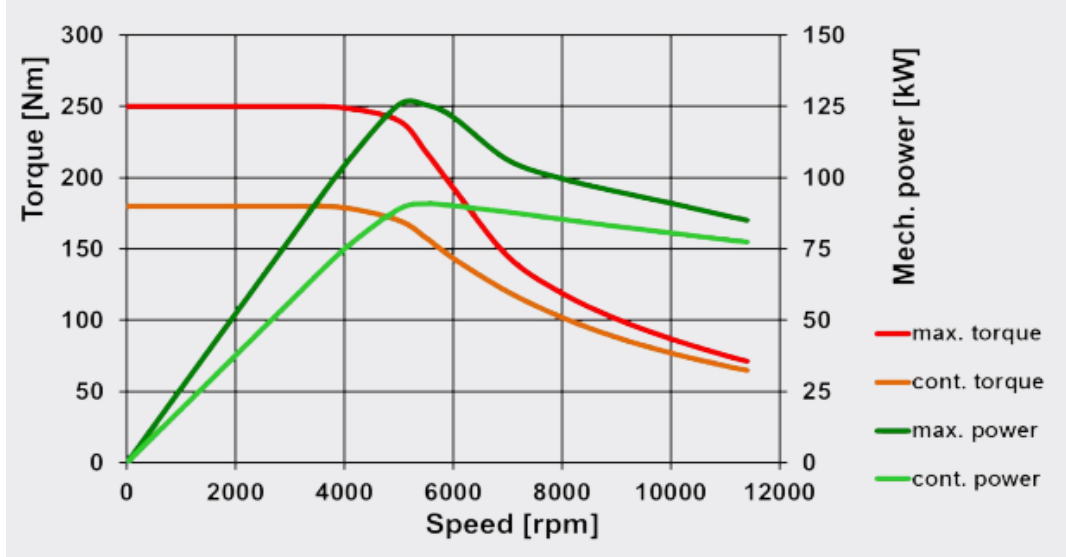

Рисунок 2 - Швидкісна характеристика електродвигуна BRASA HSM1-12/18/13

Помітимо, що цей двигун може бути встановлено на першому або другому причепі. Остаточний вибір розташування буде зроблений після аналізу маневреності метробуса.

На попередньому етапі маневреність метробуса можна розглядати на жорстких у бічному напрямку колесах $[7,8,9]$. Схема повороту метробуса на жорстких у бічному напрямку колесах за некерованих коліс причепів наведена на рис. 3, а за керованих коліс причепів - на рис. 4. 


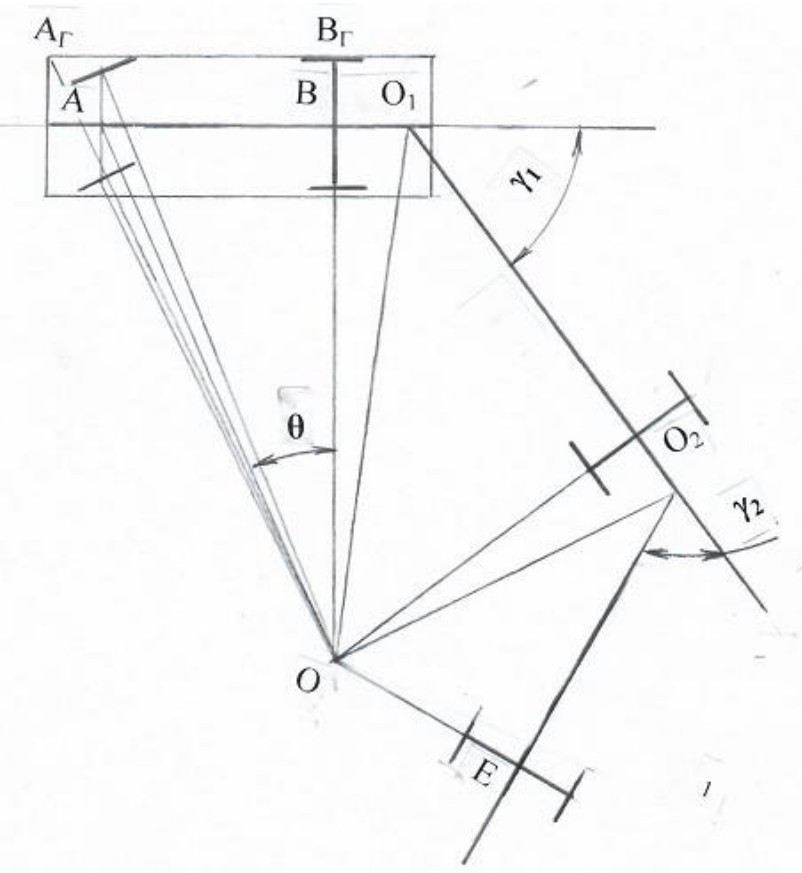

Рисунок 3 - Схема повороту метробуса на жорстких у бічному напрямку колесах

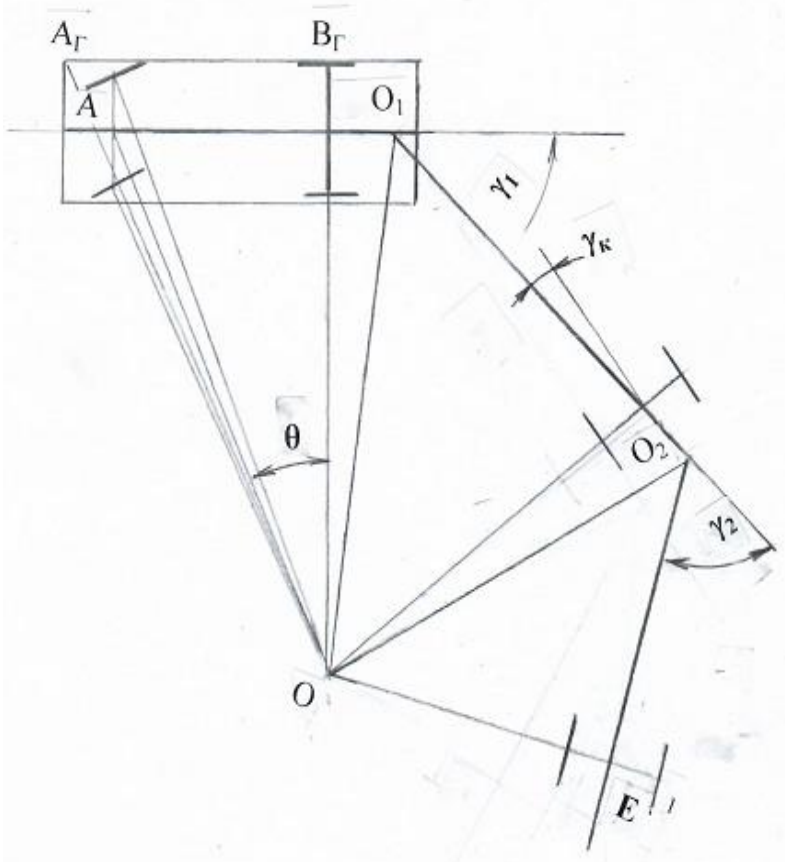

a)

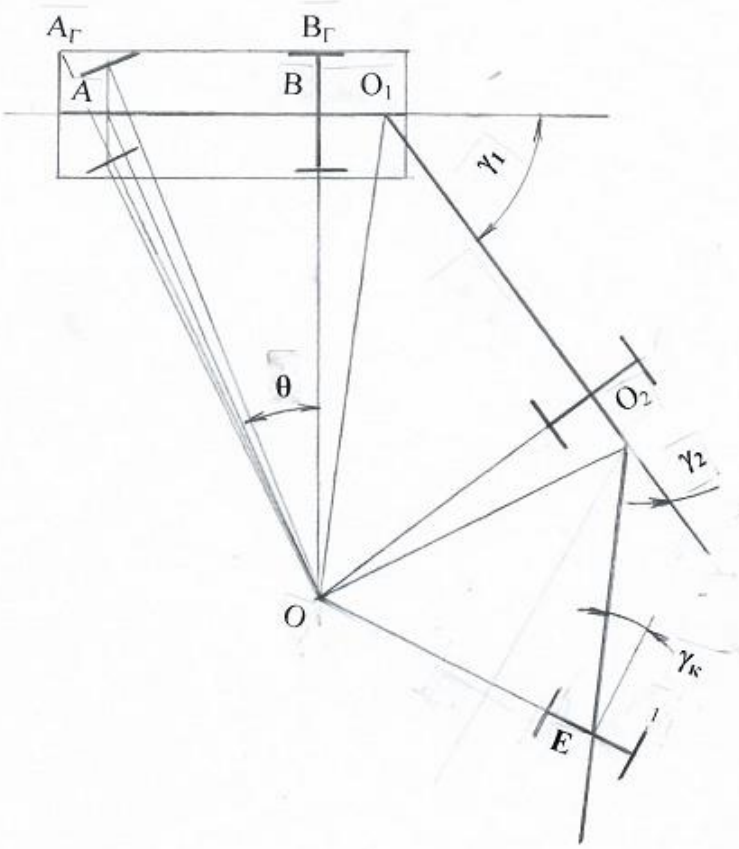

б)

Рисунок 4 - Схема повороту метробуса на жорстких у бічному напрямку колесах за керованих коліс першого причепа (a) і другого причепа (б)

Визначимо габаритні радіуси повороту і габаритну смугу руху (ГСР) для метробуса за різних схем управління поворотом. При цьому приймемо до уваги те, що ГСР транспортних засобів, у тому числі і метробуса, визначається за їх колового руху. Компонувальні параметри метробуса наведені на рис.1. У якості задаючого параметра приймемо зовнішній габаритний радіус - радіус вектор точки $\mathrm{A}_{\Gamma}=12,5$ м. Послідовно визначаючи $3 \Delta \mathrm{OA}_{\Gamma} \mathrm{B}_{\Gamma}$ відрізок $\mathrm{OB}_{\Gamma} \mathrm{i}$ далі відрізок $\mathrm{OB}, 3 \Delta \mathrm{OBO}_{1}$ відрізок $\mathrm{OO}_{1}, 3$ $\Delta \mathrm{OO}_{2} \mathrm{C}$ відрізок $\mathrm{OC}$, з $\Delta \mathrm{OCE}$ відрізок $\mathrm{OE} \mathrm{і} \mathrm{далі} \mathrm{внутрішній} \mathrm{габаритний} \mathrm{радіус}$

$$
\mathrm{R}_{\mathrm{Br}}=\mathrm{OE}-0,5 \mathrm{~B}_{\mathrm{rI}} \text {, }
$$

де $\mathrm{B}_{\text {гп }}$ - габаритна ширина причепа, $\mathrm{B}_{\text {гп }}=2,5$ м. 
У результаті розрахунків отримаємо $\mathrm{R}_{\mathrm{B \Gamma}}=4,87 \mathrm{M}, \Gamma \mathrm{CP}=\mathrm{R}_{3 \Gamma}-\mathrm{R}_{\mathrm{Br}}=12,5-4,87=7,63 \mathrm{~m}>[\Gamma \mathrm{CP}=7,2 \mathrm{M}]$.

За наведеною методикою визначимо необхідні кути повороту коліс першого або другого причепа, які забезпечили б нормоване значення внутрішнього габаритного радіусу повороту $\mathrm{R}_{\mathrm{Br}}=5,2 \mathrm{M}$ і необхідну величину ГСР.

У разі керованих коліс першого причепа необхідний середній кут повороту його коліс складе $14,2^{0}$, а другого причепа $-5,4^{0}$.

Подальший аналіз варіантів компонувальної схеми метробуса проведемо у двох напрямках:

перший - колеса першого причепа є ведучими з приводом від електродвигуна, встановленого на причепі, а колеса другого причепа є керованими за кінематичного способу повороту;

другий - перший причіп є ведучим з мотор-колесами, за допомогою яких можна здійснювати поворот причепа за силовою схемою (різними за величиною, а то i напрямком моментами на внутрішньому і зовнішньому колесі), а другий причіп $є$ некерованим.

Перевагами першої компонувальної схеми $є$ можливість іiі реалізації при широкому застосуванні стандартних комплектуючих, а основним недоліком - складність конструкції.

Перевагами другої схеми є компактність конструктивного рішення, за якого привід ведучих коліс i поворот причепа здійснюється одними і тими ж мотор-колесами, тобто для управління метробусом застосовується комбінований спосіб повороту.

У роботах $[10,11]$ отримані рівняння динаміки кругового руху машини при комбінованому способі управління поворотом

$$
\frac{d \omega}{d t}=\frac{\operatorname{tg} \bar{\alpha}}{1+\frac{b^{2}+i_{z}^{2}}{L^{2}} \operatorname{tg}^{2} \bar{\alpha}} \times\left[\begin{array}{l}
\frac{1}{m \cdot L}\left(\frac{M_{k 1}}{r_{d 1}}+\frac{M_{k 2}}{r_{d 2}}\right)-\frac{f g}{L}-\frac{f h}{L^{3}} \times \\
\times\left(V_{x 1}^{2}+b \frac{d V_{x 1}}{d t}\right) \operatorname{tg}^{2} \bar{\alpha}+\frac{B}{2 L^{2} m} \operatorname{tg} \bar{\alpha} \times \\
\times\left(\frac{M_{k 1}^{\prime \prime}-M_{k 1}^{\prime}}{r_{d 1}}-\frac{M_{k 2}^{\prime \prime}-M_{k 2}^{\prime}}{r_{d 2}}\right)
\end{array}\right],
$$

де $\omega$ - кутова швидкість автомобіля в площині дороги;

$t$ - час;

$\bar{\alpha}-$ середній кут повороту напрямних коліс,

$$
\bar{\alpha}=\frac{1}{2}\left(\alpha^{\prime}+\alpha^{\prime \prime}\right)
$$

$\alpha^{\prime} ; \alpha^{\prime \prime}$ - кути повороту внутрішнього (по відношенню до центру повороту) і зовнішнього напрямних коліс;

$b$ - відстань від задньої осі до проекції центру мас автомобіля на горизонтальну площину;

$m$ - маса автомобіля;

$L$ - поздовжня колісна база автомобіля;

$M_{k 1} ; M_{k 2}$ - сумарні крутні моменти на колесах ведучої осі автобуса і причепа, відповідно;

$r_{d 1} ; r_{d 2}$ - динамічні радіуси ведучих коліс автобуса і причепа (приймаються $r_{d 1}=r_{d 2}=r_{d}$ );

$f$ - коефіцієнт опору кочення коліс метробуса;

$h$ - висота центра мас автомобіля (причепа);

$i_{z}$ - радіус інерції автомобіля (причепа) відносно вертикальної вісі;

$V_{x 1}$ - лінійна швидкість метробуса у напрямку поздовжньої осі;

$M_{k 1}^{\prime} ; M_{k 1}^{\prime \prime}$ - крутні моменти на внутрішньому і зовнішньому ведучих колесах автобуса, $M_{k 1}^{\prime}=$ $M_{k 1}^{\prime \prime}$;

$M_{k 2}^{\prime} ; M_{k 2}^{\prime \prime}$ - крутні моменти на внутрішньому і зовнішньому ведучих колесах причепа.

Із рівняння (4) видно, що різниця крутних моментів на ведучих колесах 


$$
\Delta M_{k 1}=M_{k 1}^{\prime \prime}-M_{k 1}^{\prime}
$$

Ta

$$
\Delta M_{k 2}=M_{k 2}^{\prime \prime}-M_{k 2}^{\prime}
$$

збільшують кутове прискорення $d \omega / d t$ метробуса у площині дороги. Якщо змінити знак вказаних різниць на протилежний в рівнянні (4), то можна досягнути ситуації при якій $d \omega / d t=0$.

Представимо рівняння (4) у вигляді

$$
\frac{d \omega}{d t}=a(\alpha)[b(M)-c-d(v, \alpha)+k(\alpha, M)],
$$

де $a(\alpha)=\frac{\operatorname{tg} \bar{\alpha}}{1+\frac{b^{2}+i_{z}^{2}}{L^{2}} \operatorname{tg}^{2} \bar{\alpha}}$,

$b(M)=\left[\frac{1}{m \cdot L}\left(\frac{M_{k 1}}{r_{d 1}}+\frac{M_{k 2}}{r_{d 2}}\right)\right]$,

$c=\frac{f g}{L}$,

$d(v, \alpha)=\left[\frac{f h}{L^{3}} \times\left(V_{x 1}^{2}+b \frac{d V_{x 1}}{d t}\right) \operatorname{tg}^{2} \bar{\alpha}\right]$,

$k(\alpha, M)=\left[\frac{B}{2 L^{2} m} \operatorname{tg} \bar{\alpha} \times\left(\frac{M_{k 1}^{\prime \prime}-M_{k 1}^{\prime}}{r_{d 1}}-\frac{M_{k 2}^{\prime \prime}-M_{k 2}^{\prime}}{r_{d 2}}\right)\right]$.

При визначенні складових рівняння (8) враховано, що між кутом повороту керованих коліс автобуса (причепа) і швидкістю метробуса існує залежність [12]

$$
v_{k p y}=\sqrt{\left(\left(\frac{\sqrt{\varphi^{2}-f^{2}}}{\operatorname{tg} \alpha}-f\right) g L \cos \alpha\right)},
$$

де $v_{k p y}$ - критична швидкість по керованості;

$\varphi$ - коефіцієнт зчеплення коліс з дорогою;

$f$ - коефіцієнт опору кочення коліс;

$g$ - прискорення вільного падіння;

$L-$-база автобуса.

Оскільки розглядається другий спосіб повороту метробуса шляхом повороту причепа за силовою схемою (різними за величиною, а то i напрямком моментами на внутрішньому $\mathrm{i}$ зовнішньому колесі), то розрахунок критичної швидкості виконаємо саме для причепа за таких вихідних даних:

$b=3,25 \mathrm{м} ; m=11500$ кг; $L=6,5 \mathrm{м} ; r_{d 1}=r_{d 2}=r_{d}=0,526 \mathrm{м} ; f=0,02 ; h=1,25 \mathrm{м} ;-$ висота центра мас причепа; $i_{z}^{2}=6,25 \mathrm{~m}^{2}$.

На рис. 5 наведена залежність критичної швидкості по керованості для автобуса як складової метробуса, що розглядається. 


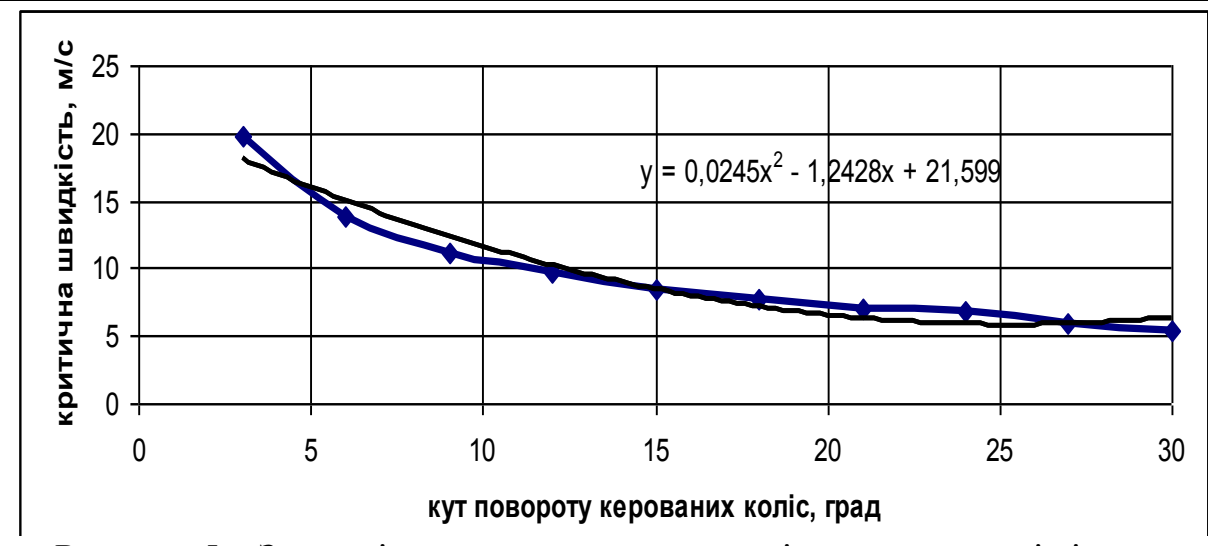

Рисунок 5 - Залежність критичної швидкості по керованості від кута повороту керованих коліс автобуса

Оскільки між швидкістю по керованості і кутом повороту керованих коліс існує певна залежність у подальшому у всіх розрахунках використовувалися відповідні значення швидкості $v_{\mathrm{x}} \mathrm{i}$ кута повороту керованих коліс $\alpha$ причепа.

Показники маневреності автотранспортних засобів, як відмічалося раніше, визначають за колового руху. При цьому кутове і окружне прискорення дорівнюють нулю, тобто $\frac{d \omega}{d t}=0 \mathrm{i} \frac{d V_{x l}}{d t}=0$. Оскільки коефіцієнт $a(\alpha) \neq 0$, то

$$
b(M)-c-d(v, \alpha)+k(\alpha, M)=0
$$

Розв'яжемо рівняння (11) відносно $\alpha$. При цьому врахуємо, що при усталеному русі складові рівняння (11) $b(\mathrm{M})$ і $c$ рівні між собою (при маневреності метробуса з незначною швидкістю силою опору повітря можна знехтувати), тобто

$$
b(M)=\left[\frac{1}{m \cdot L}\left(\frac{M_{k 1}}{r_{d 1}}+\frac{M_{k 2}}{r_{d 2}}\right)\right]=\frac{f g}{L} .
$$

За цієї умови

$$
d(v, \alpha)=k(\alpha, M) .
$$

Подальші розрахунки проведемо для двох умов руху метробуса. За першої умови задаємо швидкість руху сталою, рівною 5 м/с і визначаємо необхідну різницю крутних моментів на колесах причепа, за другої умови 3 рис. 5 вибираємо кут повороту керованих коліс і відповідно йому швидкість руху метробуса і знову ж визначаємо різницю моментів на колесах причепа.

На рис. 6 представлена залежність різниці крутних моментів на колесах осі причепа, що відповідає куту повороту його керованих коліс для двох умов руху при русі по кривій заданого радіуса.

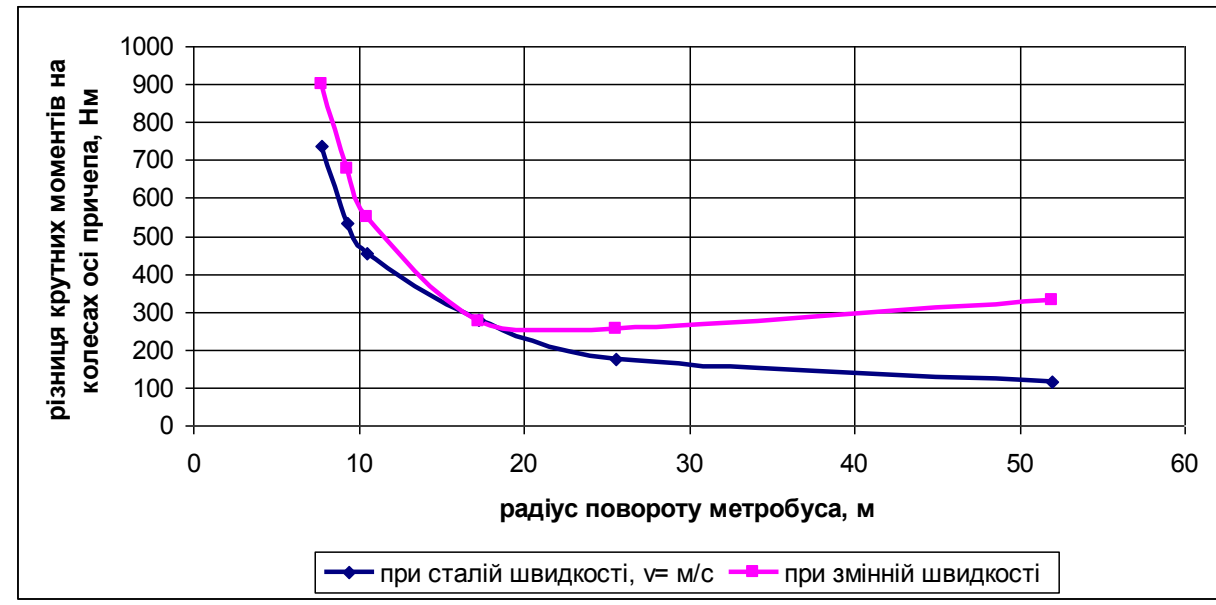

Рисунок 6 - Залежність різниці моментів на колесах осі причепа для забезпечення руху метробуса по колу заданого радіуса 
Як слідує з рис. 6 , при фіксованій швидкості повороту, $v=5 / c$, різниця крутних моментів на внутрішньому і зовнішньому колесі причепа при русі по кривим малого радіусу прогресивно збільшується. Пояснюється це нелінійною зміною величини $\operatorname{tg} \alpha$ для забезпечення необхідного радіусу повороту метробуса. У той же час урахування швидкості руху і її зв'язку з радіусом повороту (через кут повороту керованих коліс) у наведеній залежності, рис.6, призводить до того, що різниця крутних моментів на колесах причепа зменшується при збільшенні радіуса до 18 м (що відповідає необхідному куту повороту коліс причепа для досягнення нормованих показників маневреності) $\mathrm{i}$ залишається майже незмінною у всьому діапазоні зміни радіусу повороту.

Таким чином, для забезпечення необхідного рівня маневреності метробуса різниця крутних моментів на колесах причепа повинна бути не меншою $\Delta \mathrm{M}=275$ Нм.

Висновки. Встановлена необхідна пасажиромісткість метробуса, його масові і габаритні параметри. Визначена потужність гібридної силової установки. Показано, що на попередньому етапі маневреність метробуса можна розглядати на жорстких у бічному напрямку колесах. За обраних компонувальних параметрів метробуса його маневреність не відповідає діючим нормативним документам.

Розглянуті кінематичний і силовий способи повороту причепа до поліпшення маневреності метробуса. Встановлені необхідні кути повороту керованих коліс першого або другого причепа. Показані переваги силового способу повороту колесами причепа. Визначена необхідна різниця крутних моментів на колесах причепа, за якої радіус повороту метробуса був би таким, як і 3 керованим першим причепом за кінематичного способу повороту. При сталій швидкості повороту, $v=5 / \mathrm{c}$, і змінній швидкості руху і їі зв'язку з радіусом повороту для забезпечення необхідного рівня маневреності метробуса різниця крутних моментів на колесах причепа повинна бути не меншою $\Delta \mathrm{M}=275 \mathrm{Hм}$.

Подальший розвиток. Показники маневреності метробуса, що визначені на жорстких у бічному напрямку колесах, потребують аналітичної і експериментальної перевірки з урахуванням бічного відведення коліс метробуса. Цьому будуть присвячені подальші дослідження.

1. Giancarlo Genta, Lorenzo Morello, Francesco Cavallino, Luigi Filtri. The Motor Car: Past, Present and Future - Springer Dordrecht Heidelberg New York London, 2014. XXIV, 662 p. 418 illus. — ISBN 978-94-007-8551-9, ISBN 978-94-007-8552-6 (eBook), DOI 10.1007/978-94-007-8552-6.

2. Ehsani M., Gao Y., Emadi A. Modern Electric, Hybrid Electric, and Fuel Cell Vehicles: Fundamentals, Theory, and Design / Second Edition. CRC Press, 2010. 557p. International Standard Book Number (ISBN):978-1-4200-5398-2.

3. Mastinu G., Gobbi M., Miano C. Optimal Design of Complex Mechanical Systems: With Applications to Vehicle Engineering Springer, 2006. 403 p. ISBN:3540343547.

4. Бажинов О.В., Смирнов О.П., Сєріков С.А., Гнатов А.В., Колєсніков А.В. Гібридні автомобілі. - Харків, ХНАДУ, 2008. $-327 \mathrm{c}$.

5. Высоцкий М. С. Основы проектирования модульных магистральных автопоездов / М. С. Высоцкий, С. И. Кочетов, С. В. Харитончик. - Минск : Беларус. навука, 2011. - 392 с.

6. Сахно В.П. та ін. Експлуатаційні властивості автотранспортних засобів. В 3 ч. Ч 1. Динамічність та паливна економічність автотранспортних засобів: [навчальний посібник] /В.П.Сахно, А.П.Костенко, М.І.Загороднов та ін.-Донецьк: Вид-во «Ноулідж» (донецьке відділення), 2014.- 444 с.

7.Закин Я.Х. Прикладная теория движения автопоезда /Я.Х.Закин - М.: Транспорт, 1967. - 225 с.

8. Трехзвенные автопоезда /Я.Е.Фаробин, А.М.Якобашвили, А.М.Иванов и др. Под общ. ред. Я.Е.Фаробина Машиностроение, 1993. - 224 с.: ил.

9. Триланкові автопоїзди. Маневреність / В.М. Поляков, В.П. Сахно. К.:НТУ. 2013. - 200 с.: іл.

10. Маневренность и тормозные свойства колёсных машин. М.А. Подригало, В.П. Волков, В.И. Кирчатый, А.А. Бобошко. Изд-во ХНАДУ, 2003. 403 с.

11. Бобошко А.А. Нетрадиционные способы поворота колесных машин. - Харьков: Изд-во ХНАДУ, 2006. - 172 с.

12. Смирнов Г. А. Теория движения колесных машин.- М.: Машиностроение, 1990. -352 с.

\section{REFERENCES}

1. Giancarlo Genta, Lorenzo Morello, Francesco Cavallino, Luigi Filtri. The Motor Car: Past, Present and Future - Springer Dordrecht Heidelberg New York London, 2014. XXIV, 662 p. 418 illus. — ISBN 978-94-007-8551-9, ISBN 978-94-007-8552-6 (eBook), DOI 10.1007/978-94-007-8552-6.

2. Ehsani M., Gao Y., Emadi A. Modern Electric, Hybrid Electric, and Fuel Cell Vehicles: Fundamentals, Theory, and Design / Second Edition. CRC Press, 2010. 557p. International Standard Book Number (ISBN):978-1-4200-5398-2.

3. Mastinu G., Gobbi M., Miano C. Optimal Design of Complex Mechanical Systems: With Applications to Vehicle Engineering Springer, 2006. 403 p. ISBN:3540343547.

4. Bazhinov OV, Smirnov O.P., Serikov S.A., Gnatov A.V., Kolesnikov A.V. Hybrid cars. - Kharkiv, KhNADU, 2008. - 327 p.

5. Vysotsky, M.S. Fundamentals of designing modular highway trains / M.S. Vysotsky, S.I. Kochetov, S.V. Kharitonchik. Minsk: Belarus. nuvi, 2011. - 392 pp. ISBN 978-985-08-1268-1.

6. Sakhno VP etc. Operational properties of motor vehicles. At $3 \mathrm{hrs}$. 1. Dynamism and fuel efficiency of motor vehicles: [manual] /V.P.Sakhno, A.P.Kostenko, M.I. Zagorodnov and others-Donetsk: "Noulig" Donetsk, 2014-44 pp. 
7. Zakin Y.H. Applied theory of the movement of a train / Ya.K.Zakin - M .: Transport, 1967. - 225 p.

8. Three-way trains / Ya.E.Farobin, A.M. Yakobashvili, A.M.Ivanov and others. In common. edit Ya.E.Farobin. - Mechanical Engineering, 1993. - $224 \mathrm{pp} . . \mathrm{Il}$.

9. Three-axle trains. Maneuverability / V.M. Polyakov, V.P. Sakhno K.: NTU. 2013. - 200 s .: il.

10. Maneuverability and brake properties of wheeled cars. MA. Underdog, VP Volkov, VI Kirchaty, AA Boboshka Publishing house KhNADU, 2003. 403 p.

11. Boboshko AA Unconventional ways of turning wheel cars. - Kharkiv: Publishing House of KhNADU, 2006. - 172 p.

12. Smirnov GA Theory of the Movement of Wheeled Machines.- M .: Mashinostroenie, 1990. - 352 p.

Сахно В.П., Поляков В.М., Мурованый И.С., Шарай С.М. К выбору и обоснованию компоновочной схемы метробуса особо большой вместимости

Рассмотрены кинематический и силовой способы поворота прицепа для улучшения маневренности метробуса. Установлены необходимые углы поворота управляемых колес первого или второго прицепа, при которых обеспечиваются нормируемые показатели маневренности. Показаны преимущества силового способа поворота колесами прицепа. Определена необходима разница крутящих моментов на колесах прицепа, при которой радиус поворота метробуса был бы таким, как и с управляемым первым прицепом с использованим кинематического способа поворота.

Ключевые слова: метробус, прицеп, маневренность, смещение, габаритная полоса движения, гибридная силовая установка, траектория.

Sakhno V.P., Polyakov V.M., Murovany I.S., Sharay S.M. Before choosing and substantiating the layout scheme of the metro bus of a particularly large capacity

The kinematic and power traversing methods of the trailer rotation are considered in order to improve the maneuverability of the metrobus. The necessary angles of rotation of the controlled wheels of the first or second trailer are established, in which the standardized indicators of maneuverability are provided. The advantages of the power of rotation by the wheels of the trailer are shown. The required torque difference on the trailer wheels was determined, in which the radius of rotation of the metrobus would be the same as that of the first trailer controlled by the cinematic rotation method.

Keywords: metrobus, trailer, maneuverability, displacement, overall speed, hybrid power plant, trajectory.

АВТОРИ:

САХНО Володимир Прохорович, доктор технічних наук, професор, завідувач кафедри автомобілів, Національний транспортний університет e-mail: svp_40@ukr.net.

ПОЛЯКОВ Віктор Михайлович, кандидат технічних наук, доцент, професор кафедри автомобілів, Національний транспортний університет e-mail: poljakov_2006@ukr.net.

МУРОВАНИЙ Ігор Сергійович, кандидат технічних наук, доцент, завідувач кафедри автомобілів і транспортних технологій, Луцький національний технічний університет e-mail: igor_lntu@ukr.net.

ШАРАЙ Світлана Михайлівна, кандидат технічних наук, доцент, професор кафедри міжнародних перевезень та митного контролю, Національний транспортний університет е-mail: sharay_svoliacable.com

\section{ABTOРЫ:}

САХНО Владимир Прохорович, д.т.н., профессор, заведующий кафедрой «Автомобили», Национальный транспортный университет, e-mail: sakhno@ntu.edu.ua

ПОЛЯКОВ Виктор Михайлович, кандидат технических наук, доцент, профессор кафедры «Автомобили», Национальный транспортный университет, e-mail: poljakov_2006@ukr.net

МУРОВАНЫЙ Игорь Сергеевич, кандидат технических наук, доцент, заведующий кафедрой автомобилей и транспортных технологий, Луцкий НТУ, e-mail: igor lntu@ukr.net

ШАРАЙ Светлана Михайловна, кандидат технических наук, доцент, профессор кафедры международных перевозок и таможенного контроля, Национальный транспортный университет, еmail: Svetasharai@gmail.com

\section{AUTHORS:}

Volodymyr SAKHNO, Doctor of Science in Engineering, Professor, Head of Automobiles Department, National Transport University, e-mail: sakhno@ntu.edu.ua

Victor POLYAKOV, Ph.D., associate professor, professor of «Automobiles», National Transport University, e-mail: poljakov_2006@ukr.net

Igor MUROVANYI, PhD. in Engineering, Assoc. Professor, Head of Motor Cars and Transport Technologies Department, Lutsk National Technical University, e-mail: igor Intu@ukr.net

Svitlana SHARAI, PhD. in Engineering, Associate Professor, Professor, Department of International Transport and Customs Control, National Transport University, e-mail: Svetasharai@gmail.com.

Стаття надійшла в редакцію 17.04.2019 р. 